\title{
Impacts of Bureaucratic Corruption on Socio-Political and Economic Development in Africa
}

\section{Gauri Pande*}

Department of Philosophy, Delhi University, New Delhi, India

\begin{abstract}
"Corruption deprives our young citizens of opportunities to develop meaningful livelihoods." The aforesaid was spoken by the Nigerian President Muhammad Buhari at the $30^{\text {th }}$ African Union Summit which took place at the beginning of 2018. The goal of the summit was to construct new ways to end corruption and promote transparency on the part of Government and the society. Africa has been a victim of corruption for decades now. According to Transparency International, $80 \%$ of the African Population earns less than \$2 per day. With such low level of income, the inhabitants must face daily struggle to procure food and address basic health issues. The Government is deeply exhausted trying to find ways to fix the problem of corruption as it is rotting the nation from the inside.
\end{abstract}

Keywords: Corruption; Government; Transparency; Population

\section{Introduction}

Corruption can be observed in various forms, such as bribery, embezzlement, extortion and nepotism. Each one of these forms are equally responsible for stunting the growth of the nation. Bribery is the sincerest form of corruption observed in Public and Private sector. Corruption forms a vicious cycle of social instability and inequality. It is the result of these corruptive practices that one can observe a steep difference in the economy of Africa. While there are sectors which are flourishing, majority of population is still struggling for basic necessities. It is the biggest reason of the socio-economic inequality spread across the entire subcontinent of Africa [1,2].

\section{Discussion}

Corruption is not only hindering the development of Africa, but it is also unable to put a stop on the rising level of terrorism specially in Ghana, Mozambique etc. It is due to such practices that Terrorism becomes undeniably easy in such countries. With the presence of unrecorded money; terrorists and easily move their funds from one place to other. The rising level of terror has lead the entire world in a state of perplex. Measures are taken, and they fail. It evidently proves that corruption in Africa has reached a level where it could be assumed that bureaucrats have taken a long swim in the pool of corruptive practices. All election campaigns for the past several years have emphasised on Corruption and each political party has promised to eradicate corruption from its roots [3]. Various measures have been taken to abort the corruptive practices on the part of the Government and Public offices, but nothing has presented conclusive results.

African subcontinent falls under one of the most underdeveloped regions of the world. Inspite of various schemes introduced by the government to enrich the lives of African citizens, all their efforts have proved to be absolutely worthless because of the corruptive bureaucratic practices running in Africa. The living conditions of majority of population are deplorable and these situations do not seem to improve any time soon. While there are nations who have extraordinary level of health and prosperity ratios, Africa is still dealing with troubles faced by underdeveloped nations. It is this practice of corruption that Africa stands as the number one country in malnourishment, poverty and lack of education. The children residing in that country are underprivileged to such an extent that most of them do not live long enough to experience their youth. A deep distress has taken over the inhabitants of the subcontinent and the only thing which could provide them any solace would be to finally form a government which takes robust measures to end corruption.

\section{Conclusion}

After several failed attempts to fight Corruption, the nation has finally decided to take severe corrective measures in order to establish health and prosperity in Africa [4]. Africa began the year 2018 with a strong determination to fight the problem of Corruption. President Buhari assured the citizens in the AU Summit that Africa will no longer remain under the vile shadow of corruption. It is time to take extensive measures and bring an end to corruption once and for all. Not only is the Government taking serious attempts to fight corruption by implementing various policies, but they have also planned to establish various committees which will ensure non-corruptive practices in the Country. The purpose of establishing these committees solely for the purpose of fighting corruption is that they will be able to note any corruptive practices which may take place in the subcontinent and thereby move a step closer in order to abolish them [5]. Thus, it can be hoped that soon Africa will rise above the cloud which has darkened the economy and the socio-political life of its citizens for years.

\section{References}

1. Silva CR (2018) African Union Summit: Fight against corruption at the centre stage. Mo Ibrahim Foundation.

2. Gossel S (2017) How corruption is fraying South Africa's social and economic fabric. The Conversation Media Group Ltd, South Africa.

3. Kaninda S (2018) The African union kicks off 2018 with an anti-corruption campaign. Transparency International, Africa.

4. Gumede M (2012) Why fighting corruption in Africa fails, Pambazuka News.

5. Transparency International (2018) The global anti-corruption coalition.

*Corresponding author: Gauri Pande, Department of Philosophy, Delhi University, New Delhi, India, Tel: +91-8860812374; E-mail: gauripande1996@gmail.com

Received June 15, 2018; Accepted June 25, 2018; Published June 29, 2018

Citation: Pande G (2018) Impacts of Bureaucratic Corruption on Socio-Political and Economic Development in Africa. Review Pub Administration Manag 6: 249. doi:10.4172/2315-7844.1000249

Copyright: ( $) 2018$ Pande G. This is an open-access article distributed under the terms of the Creative Commons Attribution License, which permits unrestricted use, distribution, and reproduction in any medium, provided the original author and source are credited. 